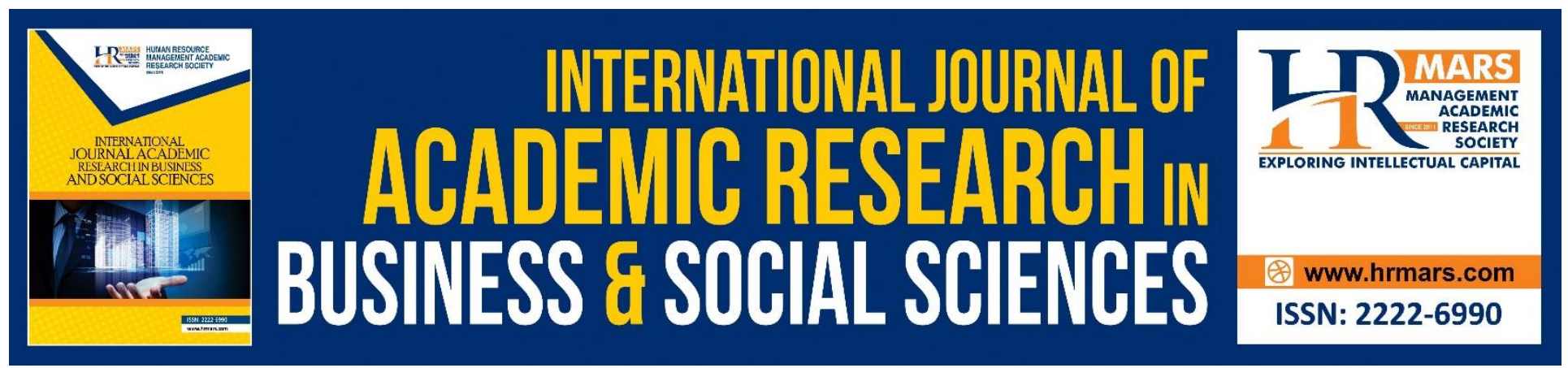

\title{
Well-being and Organizational Pride in the Royal Malaysian Police Force: An Initial Investigation
}

\author{
Mohd Razali Alias, Arsiah Bahron
}

To Link this Article: http://dx.doi.org/10.6007/IJARBSS/v9-i6/5961

DOI: $10.6007 /$ IJARBSS/v9-i6/5961

Received: 16 April 2019, Revised: 21 May 2019, Accepted: 06 June 2019

Published Online: 24 June 2019

In-Text Citation: (Alias \& Bahron, 2019)

To Cite this Article: Alias, M. R., \& Bahron, A. (2019). Well-being and Organizational Pride in the Royal Malaysian Police Force: An Initial Investigation. International Journal of Academic Research in Business and Social Sciences, 9(6), 418-427.

\section{Copyright: (C) 2019 The Author(s)}

Published by Human Resource Management Academic Research Society (www.hrmars.com)

This article is published under the Creative Commons Attribution (CC BY 4.0) license. Anyone may reproduce, distribute, translate and create derivative works of this article (for both commercial and non-commercial purposes), subject to full attribution to the original publication and authors. The full terms of this license may be seen

at: $\underline{\text { http://creativecommons.org/licences/by/4.0/legalcode }}$

Vol. 9, No. 6, 2019, Pg. 418 - 427

http://hrmars.com/index.php/pages/detail/IJARBSS

JOURNAL HOMEPAGE

Full Terms \& Conditions of access and use can be found at http://hrmars.com/index.php/pages/detail/publication-ethics 


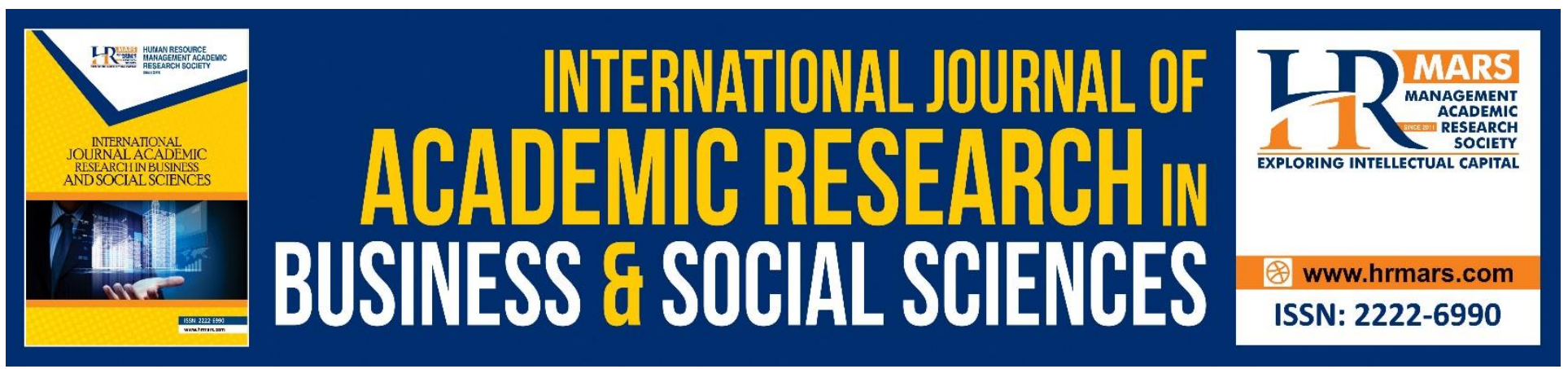

\title{
Well-being and Organizational Pride in the Royal Malaysian Police Force: An Initial Investigation
}

\author{
Mohd Razali Alias, Arsiah Bahron \\ Faculty of Business, Economics and Accountancy, Universiti Malaysia Sabah, 88400 Kota Kinabalu, \\ Malaysia
}

\begin{abstract}
The purpose of this study is to examine the well-being and organizational pride among police officers in the Malaysian Royal Police Force. A critical review of relevant literature involving 30 studies that focus on organizational pride will conduct. The review has identified four distinct constructs of organizational pride: (i) introspective pride, (ii) vicarious pride, (iii) contagious pride, and (iv) conspicuous pride. In addition, other relate well-being factors associate with pride include: (i) emotional organizational pride, (ii) attitudinal organizational pride, (iii) commitment to customers service, and (iv) creativity. Pride was found to be positively associated with individual morale and organizational performance. However, in the context of methodology, there is an over-reliance on quantitative, cross-sectional and self-report studies within the field relate to pride. To address this issue, future research should employ more qualitative and sociological methodologies.
\end{abstract}

Keywords: Well-being, Organizational Pride, Royal Malaysian Police, Police Officers, Malaysia

\section{Introduction}

According to (Cheah et al, 2018) formal law enforcement in Malaysia begins from the island of Penang as a British colony in 1786 followed by the establishment of a police force there in 1807. Early policing in Penang appears much more militaristic in organization. In Malaysia, the official responsibilities of the police are listed in Section 3(3) of the Police Act 1967. Currently, the Royal Malaysia Police (RMP) is centralized and controlled by the Federal Government in Putra Jaya within the Ministry of Home Affairs. It is headed nationally by an Inspector-General of Police and organized as follows: there are 14 police contingents in Malaysia. Each contingent is led by a Chief Police Officer or Commissioner of Police. The RMP's motto is Bersedia Berkhidmat (in English: "Ready to Serve"). This indicates the RMP's focus on police-commitment in ground duty, an initiative in which police officer's confidence as the organizational pride is the focus of this study in order to acquire professionalism and organizational identities framed.

According to Mathias and Miriam (2011), organizational pride is an important factor in the success of a business that is rarely explored. Several studies have associated organizational pride to perseverance and achievement (Williams \& DeSteno, 2008; Fredrickson, 2013). In some studies, 
organizational pride has been perceived as a noble characteristic and in some studies as a vice (William \& DeSteno, 2008). A strong association has been found between emotional organizational pride and attitudinal organization pride as well as having a positive effect on commitment to customer service (Matthias \& Miriam, 2011).

Organizational pride is a major concern that has not been explored extensively in respect to the Malaysia Police Force. It brings into perspective the relationship between the affective construct and organizational pride. Organizational pride can be leveraged to improve performance and organizational image especially in public sector entities such as the police. Increased organizational pride has been linked to positively influencing job satisfaction in the workplace.

To address these issues, the aim of this paper is:

i. To define and discuss the concept of organizational pride among police officer.

ii. To study part research on organizational pride among police officer.

iii. To identify factor related organizational pride among police officers Royal Malaysia Police.

\section{Literature Review}

\section{Concept of Organizational Pride}

Pride emanates from the feeling of delight, pleasure or satisfaction in one's capability or achievements (Welander, Wallin, \& Isaksson, 2017). In most cases, pride arises in the context of highinvolvement decisions or settings (Lea \& Webley, 1997). Pride is attributed to the need for self and social identity processes and is conceived as an aspect of self-consciousness or an ego-focused and competitive emotion which entails the involvement of an individual in dealing with inner conflicts in pursuit for inner identity and glory (Tangney, Burggraf, \& Wagner, 1995; Tangney, 2005; Lewis, 2000). It is through pride that self-esteem gains its affective kick according to Brown and Marshall, (2001).

In organizational management literature, pride is ignited by recognition that is achieved through social admiration or approval (Zammuner, 1996). It is an emotion that is derived from selfappraisals and appraisals by others and is often based on the belief in one's competence and behavior being valued by others (Tracy \& Robins, 2004; Arnett, 2002; Scheff, 1991). In essence, results from the favourable comparisons of self to others that seek to raise the social status and minimize the sense of similarity to others (Oveis et al., 2010). Pride usually persists in the face of adversity and is characterized by an individual's effort to exert control or mastery over others (Tracy \& Robins, 2004). There exist several typologies of pride in the psychosocial literature including hubris, individual pride, group pride, positive pride, among other forms of pride. Excessive pride is referred to as hubris and together with positive pride arises from internal attribution (Lewis, 2000; Tangney, 2005; Verbeke et al 2004). Another form of pride is individual pride that results from personal achievements while group pride is derived from collective identities (Tracy and Robins, 2007).

\section{Organizational Pride Dimensions}

Organizational pride is fundamentally a constructed that has been widely explored in psychology with a focus on the relationship between employees and the organization. It is used to describe the positive feeling that is derived through assessment of the organization's relative status (Haslam, 2004). It is the positive feeling that a worker perceives as a consequence of identifying with the 
organization's success and reputation. This makes organization pride an important component as a strategic competitive asset and significance for the performance of the organization.

Organization pride has been mentioned as a significant driver of positive workplace behavior and a distinguishing aspect in competition (Katzenbach, 2003). According to the social identity theory, customers also have organizational pride where they identify themselves with a reputable, successful and distinctive organization (Haslam, 2004). Organizational pride is a driven by several factors among them the cultural dimension that includes its customer intimacy and customer's evaluation of its perceived benefits and achievements (Daniel, 2013). Through organizational pride the organization benefits through positive word-of-mouth, brand loyalty and customer acquisition. In the context of the Malaysian police, positive behaviors towards the public entity are the main positive outcome of organization pride.

\section{Emotional Organizational Pride}

According to Averill, and Thomas-Knowles, (1991), emotional organizational pride is regarded as an intellectual emotion and is typified as a positive emotions or a secondary emotion. There are four types of pride based on two dimensions which is overtly expressed in their pride and inspired by overt and covert behavior (Decrop and Derbaix, 2010). Overt behaviors are attributes that are visible to an individual while covert behaviors include behaviors that are not visible to the naked eye. These hidden behaviors include inner feelings such as jealousy and are usually not observed or evaluated externally and can only be identified through in-depth interaction with an individual. This implies that the Malaysian police may use some objects to develop organizational pride through overt expression (Belk 1988; Schau 2000). For instance, the color of the uniform and assets can help in externalizing their pride to the members of the public. The second dimension in cultivating organization pride in Malaysian police is through individual and collective nature of identification. Identity creation and expression pertains to the establishment of individual and social identities ((Tajfel and Turner 1986; Triandis 1989). Based on the two dimensions of pride, Decrop and Derbaix (2010) describes four types of pride process that can be contextualized to the Malaysian police organization.

\section{Attitudinal Organizational Pride}

Pride has been described as an attitude and as an expression of self-esteem (Lea \& Webley, 1997). It is usually associated with achievement and can be described as an emotional response to the evaluation of one's competence. The link between pride and achievement is demonstrated in empirical studies where it is associated with the feeling of being proud as a result of one's own behavior (Lea \& Webley, 1997).

\section{Commitment to customer service}

The long-term relationship between an organization and its customers depends on organization personnel (Bowen \& Lawler, 1992). The ability of an organization to offer quality and premium customer service will depend on the willingness of the employees who should be committed to improve customer services Pride has also been described as a process through which individuals cope with their inner conflicts where they routinely search for glory and inner unity. Pride is regarded as satisfaction with an individual's own appearance and is focused towards a social position. It can be 
INTERNATIONAL JOURNAL OF ACADEMIC RESEARCH IN BUSINESS AND SOCIAL SCIENCES Vol. 9, No. 6, June, 2019, E-ISSN: 2222-6990 @ 2019 HRMARS

equated to self-deification which is not the same as a healthy self-esteem (Wilder, 1978). Organizational pride helps employees to be committed in improving customer service such that the long-term relationship between the companies can be improved.

\section{Creativity}

Pride is a self-reward and is an internal counterpart of praise. Pride is viewed as a loose interpretation of achievements. Pride is vital in stimulating employee commitment to creativity in an organization that can in turn innovation. Creativity is generated through the interaction of the organization's personnel with customers. In delivering customer services, employees encounter new challenges that require them to be innovative and produce ideas to surmount the challenges. According to Lea and Webley, (1997), pride is described as the need to associate with another person's achievements. It is used in everyday sense as a counter to destructive emotion of envy. In management, pride implies the extension of possessions like families and group such that the possessions are viewed as the extensions of self. Organizational pride as a positive emotion that has the potential to stimulate employee creativity especially when delivering customer service to improve organization performance.

\section{Distinct Construct}

The perspective of organizational pride is discussed through scholars' findings, and will be explored in this study in four distinct sub-heading that constitutes the constructs of organizational pride.

\section{Introspective Pride}

Introspective pride is generated from individual self and may help an individual police officer to build his or her own identity. The introspective pride emanates from material possessions such as uniform and other assets. According to Decrop and Derbaix (2010), study participants were intimately proud because of their possessions and this generated pride in the organization performance. In turn organizational pride led to enhancement of the individual's performance and self-confidence in the workplace. Introspective pride helps individuals to justify themselves such that they are praiseworthy and is not based merely on the job position or job description. It leads to an unfailing loyalty to the organization in order to support a "noble cause". It is the inner satisfaction of being a "true" worker (Decrop \& Derbaix, 2010). Introspective pride is associated with the private collections observed in some informants' homes that included a range of paraphernalia and memorabilia such as caps, flags, uniforms, batons and press articles among other items.

\section{Vicarious Pride}

Vicarious pride encompasses the creating the collective self. This is demonstrated by the popular song of the organization that seeks to show the extent into which the force leads to the development of group identity. "We" and "Us" appear more than any other words in the song. Other components of the collective self-include the team, its colours and the shared organization's image that every police officer is proud of. Through organizational pride, not only are individual identities created, but the collective self of the organization is supported (Lea \& Webley, 1997). The identity creation process appears to have a vicarious background where fans of the organization project themselves 
in others and in the organization's achievements. Colours appear to play a significant role in the creation of collective selves. The colours create an automatic identification with the organization and recognition of the team. The officers' possessions, deeds and gestures may also explain the officers' sense of belonging to the organization. Vicarious pride makes the members to adopt the same behaviour as others, for example shopping for clothes in the organization's shop. The vicarious pride is the source of the prestigious history of the police service and the collective pride feeling.

\section{Contagious Pride}

The contagious pride is an expression of the collective self. In the Royal Malaysia Police it involves supporting the officers on duty while respecting each other's. The service does not only wear uniform but also have a prestigious history spanning over 200 years. The police officers are proud to be the best public officers of Malaysia and when everyone sees them on duty, they are impressed. The officers wear the team's paraphernalia or overtly show support for the organization in two prominent ways including their integration within the community. As noted in Decrop and Derbaix (2010), the officers demonstrates their pride in being a component of the collection self of the organization. Most of the pride demonstrated in this context if of a contagious background and it tends to spread across the organization through direct contact of the police officers. Contagious pride may also be as a result of current organization's achievements that lead to collective pride. The officer derives their pride from an organization that is characterized by its own ethos that includes long-held cultures such as member's call sign.

\section{Conspicuous Pride}

Conspicuous pride is derived from the expression of an individual self-introspective pride and vicarious pride and support the creation of individual and collective selves respectively. It encompasses the parading organization's colors and emblems. The police officers proudly exhibited team-related clothes, banners, badges or flags in order to be seen as the greatest organization's enthusiast. All these activities aim at proudly to outdoing other organizations and showing off the greatest organization's enthusiast. The activities may be interpreted as a form of conspicuous pride, which helps police officers to express their emotions in an individual direction (Decrop and Derbaix, 2010).

\section{Methodology}

The study participants will include police officers serving in the Malaysian Royal Police Force. A pilot study will be the first conduct in order to probe whether all questionnaire items are clear and shall not confuse the study participants when responding. The sample population for the study include 100 police officer from different hierarchical levels in the force that will randomly selected via a random sampling technique. The pilot study will also help the researcher to identify the meaningfulness of the language used from the feedback from the pilot study participants. However, the data obtained from the pilot study will not be included in the final data analysis. Base on the feedback from the pilot study, the researcher will seek to improve the readability and clarity of the questionnaire items to ensure that the survey responses are accurate. From the pilot survey's feedback, the researcher will reword or delete troublesome language (if any). 
Participation in the study will be voluntary where the target respondents will be provided with a letter of informed consent that will be attached on the first page of the questionnaire with explanation of the aim of the study, the estimated time for completion of the questionnaire and a promise to ensure confidentiality and privacy of the gathered data. The study will collect demographic data of the participants including the seniority, job level and position, department in the organization among other items. In order to maximize the response rates, the researcher will provide both paper-and-pencil format as well as the online format to the police officers. The questionnaires targeted 100 police officers in the survey. Returning questionnaires will be manually checked for completeness.

\section{Conclusion}

This paper concludes that impact of pride requires the alignment of personal, professional and organizational identities will come up which is a positive organizational pride. To the best of our knowledge, it is original contribution in organizational pride in the context of Royal Malaysia Police. Royal Malaysia Police officers are exposed to their working environments, it became apparent that the pride as a professional police officer they had constructed was different - or not quite aligned with - constructions around professional identity that raise of self-esteem, confidence, a positive well attitude and satisfaction may operate the first pioneer than other agencies departments in Malaysia. Professional pride is organizational pride. New well-prestige instruction for well-being needed to adapt and adjust this positive attitude as a professional police officer to the expectations of others in order to acquire professionalism and organizational identities framed and communicated by level of hierarchy organizational officers, preceptors, organizations, public as customers and their relatives.

\section{Theoretical and Conceptual}

Professional pride (Jansen et al. (2010) theorized that :

1) Increasing attention seems to be devoted to the professional pride of public servants.

2) It is a certain emotion that actually gives rise to positive feelings.

3) The process of self-consciously publicly supporting an achievement or quality of your own, or of someone to whom you feel closely allied, simply because you believe that its value deserves broader recognition

4) Honor as the placing of high demands upon an individual's own actions so that in the eyes of others they gain a certain worth.

5) Honor and pride terms have very much to do with people's intrinsic qualities with a degree of intrinsic motivation.

6) Feelings of honor contribute to a striving toward certain behavior, while pride is much more a state of mind that leads to honor and inherently certain behavior.

7) Those who take pride in their profession are-so it is presumed- satisfied with their work because it is important and has significance, because it represents quality and is expertly executed in all good conscience. 


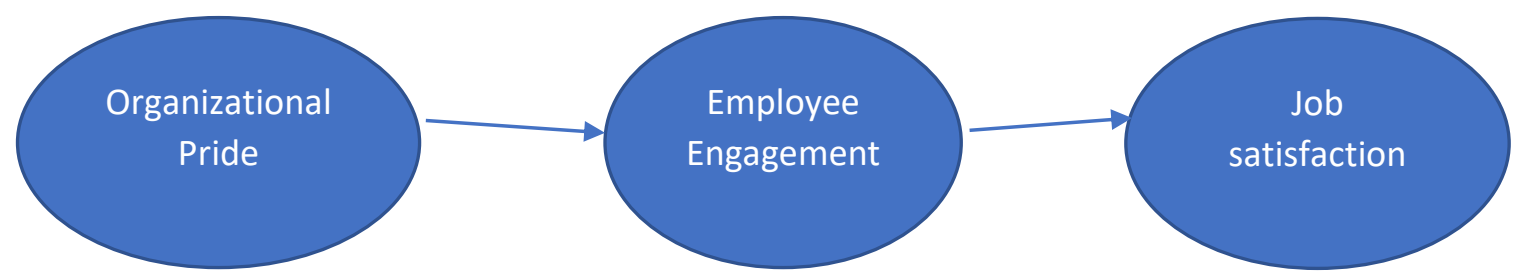

Figure

1: Conceptual Framework Organizational

Pride among Royal Malaysia Police Office

\section{Recommendations}

Several recommendations are put forward from this research thus :

1. Use information from this research to develop a detailed plan of how to create pride of police officers in Royal Malaysia Police.

2. Do a more exhaustive examination of organizational pride to determine best practices for Royal Malaysia Police officers.

3. Conduct pilot projects to measure organizational pride in the Royal Malaysian Police Force.

\section{Corresponding Author}

Mohd Razali Alias, Faculty of Business, Economics and Accountancy, Universiti Malaysia Sabah, 88400 Kota Kinabalu, Malaysia, email: adieyyusuf@outlook.my

\section{References}

Arnett, D. (2002). Using job satisfaction and pride as internal-marketing tools. The Cornell Hotel and Restaurant Administration Quarterly, 43(2), 87-96. doi:10.1016/s0010-8804(02)80035-0.

Averill, J. R., \& Thomas-Knowles, C. (1991). Emotional creativity. In K.T. Strongman (Ed.), International review of studies on emotion (1, 269-299). London: Wiley.

Belk, R. W. (1988). Possessions and the extended self. Journal of Consumer Research, 15, 139-168.

Bowen, D. E. and Lawler, I. (1992). The empowerment of service workers: what, why, how, and when, Sloan Management Review, 33(3), 31-39.

Brown, J. D., \& Marshall, M. A. (2001). Self-esteem and emotion: Some thoughts about feelings. Personality and Social Psychology Bulletin, 27, 575-584.

Cheah, P. K., Unnithan, N. P., Suppiah, S., (2018). Role reflections of police reservists : a study of volunteer reserve officers in Malaysia. Policing: An International Journal, 41(6), 813-827. doi:10.1108/PIJPSM-05-2017-0065 .

Decrop, A. \& Derbaix, C. (2010). Pride in contemporary sport consumption: a marketing perspective, 586-603.doi: 10.1007/s11747-009-0167-8.

Fredrickson, B. (2013). Positive Emotions Broaden and Build. Advances in Experimental Social Psychology, 1-53. doi: 10.1016/b978-0-12-407236-7.00001-2.

Fredrickson, B. L. (2001). The role of positive emotions in positive psychology. American Psychologist, 56(3), 218-26.

Haslam, S. A. (2004). Psychology in Organizations: A Social Identity Approach (2 ${ }^{\text {nd }}$ ed.). London, UK, Sage. 
INTERNATIONAL JOURNAL OF ACADEMIC RESEARCH IN BUSINESS AND SOCIAL SCIENCES

Vol. 9, No. 6, June, 2019, E-ISSN: 2222-6990 @ 2019 HRMARS

Hirschman, A. (1970). Exit, Voice, and Loyalty: Responses to Declines in Firms, Organizations, and Nations. Cambridge, MA: Harvard University Press.

Jansen, T., Brink, G. J. M., \& van den Kole, J. (2010). Professional Pride: A powerful force. Amsterdam, The Netherlands: Boom.

Katzenbach, J. R. (2003). Pride: a strategic asset. Strategy \& Leadership, 31(5), 34-38.

Kernaghan, K. (2011). Getting engaged: Public-service merit and motivation revisited. Canadian Public Administration, 51,1 -21. doi:10.1111/j.1754-7121.2011.00158.x Lan

Lea, S. E. G. \& Webley, P. (1997). Pride in economic psychology. Journal of Economic Psychology, 18, 323-340. DOI: https://doi.org/10.1016/S0167-4870(97)00011-1.

Lea, S. E., \& Webley, P. (1997). Pride in economic psychology. Journal of Economic Psychology, 18(23), 323-340. doi:10.1016/s0167-4870(97)00011-1.

Lewis, M. (2000). Self-conscious emotions: Embarrassment, pride, shame, and guilt. In M. Lewis \& J. M. Haviland-Jones (Eds.), Handbook of emotions (2 ${ }^{\text {nd }}$ ed., pp. 623-636). New York: Guil- ford Press.

Matthias H. J. G. \& Miriam R. (2011). Organizational pride and its positive effects on employee behavior, 22(5) 5, 633-649, https://doi.org/10.1108/09564231111174988

Müller-Peters, A. (1998) The significance of national pride and national identity to the attitude toward the single European currency: A Europe-wide comparison. Journal of Economic Psychology, 19(6),701-719.

Oveis, C., Horberg, E. J. \& Keltner, D. (2010). Compassion, pride, and social intuitions of self-other similarity. Journal of Personality and Social Psychology, 98(4), 618-630. doi:10.1037/a0017628

Schau, H. J. (2000). Consumer imagination, identity and self-expression. Advances in Consumer Research, 27, 50-55.

Scheff, T. J., \& Retzinger, S. M. (1991). Lexington Books series on social theory. Emotions and violence: Shame and rage in destructive conflicts. Lexington, MA, England: Lexington Books/D. C. Heath and Com.

Soscia, I. (2007). Gratitude, delight, or guilt: The role of consumers emotions in predicting postconsumption behaviors. Psychology and Marketing, 24(10), 871-894. doi:10.1002/mar.20188.

Tajfel, H., \& Turner, J. C. (1986). The social identity theory of intergroup behaviour. In S. Worchel \& W. G. Austin (Eds.), Psychology of intergroup relations (7-24). Chicago: Nelson.

Tangney, J. P., Burggraf, S. A., \& Wagner, P. E. (1995). Shame-proneness, guilt-proneness, and psychological symptoms. In J. P. Tangney \& K. W. Fischer (Eds.), Self-conscious emotions: The psychology of shame, guilt, embarrassment, and pride (343-367). New York, NY, US: Guilford Press.

Tangney, J. P. (2005). The Self-Conscious Emotions: Shame, Guilt, Embarrassment and Pride. Handbook of Cognition and Emotion, 541-568. doi:10.1002/0470013494.ch26

Tangney, J. P. (1999). The self-conscious emotions: Shame, guilt, embarrassment and pride. In T. Dalgleish \& M.J. Power (Eds.), Handbook of cognition and emotion (541-568). New York: John Wiley \& Sons.

Tracy, J. L. and Richard W. Robins, R. W. (2004). Putting the Self into Self-Conscious Emotions: A Theoretical Model. Psychological Inquiry, 15(2), 103-125. 
Tracy, J. L., \& Robins, R. W. (2007a). Emerging insights into the nature and function of pride. Current Directions in Psychological Science, 16, 147-150.

Tracy, J. L. \& Robins, R. W. (2007b). The psychological structure of pride: A tale of two facets. Journal of Personality and Social Psychology, 92, 506-525.

Triandis, H.C. (1989). The self and social behavior in differing cultural contexts. Psychological Review, 96, 506-520.

Verbeke, W., Belschak, F., \& Bagozzi, R. P. (2004). The adaptive consequences of pride in personal selling. Journal of the Academy of Marketing Science, 32, 386-402.

Welander, J., Wallin, J., \& Isaksson, K. (2017). Job Resources to Promote Feelings of Pride in the Organization: The Role of Social Identification. Scandinavian Journal of Work and Organizational Psychology, 2(1), 7. doi:10.16993/sjwop.23.

Wilder, W. G. (1978). The search for self-esteem. Journal of Psychology and Theology, 6(3), 183-188.

Williams, L. A., \& DeSteno, D. (2008). Pride and perseverance: The motivational role of pride. Journal of Personality and Social Psychology, 94, 1007-1017.

Vermeeren, B., \& van Geest, D. (2012). Researchnote: Professional pride and pressures ofrules in the publicsector. Tijdschrift Voor Arbeidsvraagstukken, 28, 215-328. (No doi).

Zammuner, V. L. (1996). Felt emotions, and verbally communicated emotions: The case of pride. European Journal of Social Psychology, 26(2), 233-245. doi:10.1002/(sici)10990992(199603)26:23.0.co;2-\# 